\title{
A spiral-like chain from a hydrogen-bonded cyclic dichloride contain- ing a water dimer in a quaternary diammonium dichloride trihydrate $^{\#}$
}

\author{
BIKSHANDARKOIL R SRINIVASAN,,${ }^{1, *}$ RATHAN G MHALSIKAR,${ }^{1}$ KOYAR S RANE, ${ }^{1}$ \\ CHRISTIAN NÄTHER ${ }^{2}$ and WOLFGANG BENSCH ${ }^{2}$ \\ ${ }^{1}$ Department of Chemistry, Goa University PO, Goa 403206 \\ ${ }^{2}$ Institut für Anorganische Chemie, Christian-Albrechts-Universität Kiel, Olshausenstraße 40, \\ D-24098 Kiel, Germany \\ e-mail: srini@unigoa.ac.in
}

MS received 13 July 2006; revised 22 January 2007

\begin{abstract}
The reaction of benzyl chloride with tetramethylethylenediamine (tmen) results in the formation of the quaternary diammonium dichloride trihydrate (dbtmen) $\mathrm{Cl}_{2} \cdot 3 \mathrm{H}_{2} \mathrm{O} \mathbf{1}$ (dbtmen is $\mathrm{N} \mathrm{N}^{\prime}$-dibenzyl$\mathrm{N}, \mathrm{N}, \mathrm{N}^{\prime}, \mathrm{N}^{\prime}$-tetramethylethylenediammonium) in good yields. 1 crystallises in the monoclinic $P 2_{1} / c$ space

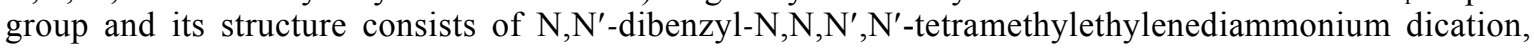
two chloride anions and three crystal water molecules all of which are located in general positions. The organic dication is $\mathrm{H}$-bonded to the chloride anions and the crystal waters with the help of intra- and intermolecular $\mathrm{C}-\mathrm{H} \cdots \mathrm{Cl}$ and $\mathrm{C}-\mathrm{H} \cdots \mathrm{O}$ interactions, while the chloride anions are linked to the crystal waters via $\mathrm{O}-\mathrm{H} \cdots \mathrm{Cl}$ interactions. One of the crystal waters is linked through an intermolecular $\mathrm{O}-\mathrm{H} \cdots \mathrm{O}$ bond with another water resulting in the formation of a water dimer. The $\mathrm{O}-\mathrm{H} \cdots \mathrm{Cl}$ and $\mathrm{O}-\mathrm{H} \cdots \mathrm{O}$ interactions between the chloride anions and water molecules lead to the formation of a five-membered $\left\{\mathrm{O}_{3} \mathrm{Cl}_{2}\right\}$ cyclic dichloride containing a water dimer. The five-membered rings are linked into a chain with the aid of a $\mathrm{O}-\mathrm{H} \cdots \mathrm{Cl}$ interaction. The organic cations are organised in zigzag fashion on either side of the chain and are further linked to the anionic water chain via weak $\mathrm{C}-\mathrm{H} \cdots \mathrm{O}$ and $\mathrm{C}-\mathrm{H} \cdots \mathrm{Cl}$ interactions, leading to the supramolecular organisation of the rings into a spiral-like of chain.
\end{abstract}

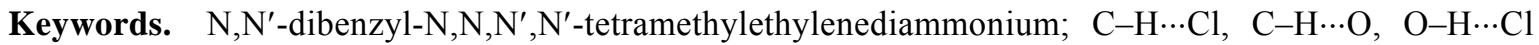
and $\mathrm{O}-\mathrm{H} \cdots \mathrm{O}$ interactions; cyclic dichloride; water dimer; spiral-like chain.

\section{Introduction}

Compounds containing organic cations and inorganic anions provide novel supramolecular networks with interesting structural features such as chirality in ethylenediammonium sulphate ${ }^{1}$ or formation of a bilayer in 2-aminoanilinium perchlorate, ${ }^{2}$ formation of sulphate anion helices in $o$-phenylenediammonium sulphate sesquihydrate ${ }^{3}$ etc. The networks become quite interesting when the cation and anion can participate in $\mathrm{H}$-bonding interactions. In crystalline hydrates, the supramolecular organisation of the cations, anions or the molecule itself, can lead to the formation of channels or cavities which can function

\footnotetext{
${ }^{\#}$ Dedicated to Prof. Sabyasachi Sarkar on the occasion of his $60^{\text {th }}$ birthday

*For correspondence
}

as a host, trapping guest molecules especially water in the form of small hydrogen bonded clusters. The results of a systematic search of the Cambridge Crystallographic Database for organic crystals containing water molecules, which show the diversity of hydrogen-bonding interactions among water molecules, ${ }^{4}$ have been recently published. ${ }^{5,6}$ Studies on water clusters are of current research interest ${ }^{7}$ as evidenced by the several recent theoretical ${ }^{8-10}$ and experimental $^{11-27}$ investigations in this area. Small water clusters have been characterized spectroscopically ${ }^{28-30}$ and clusters with $n=2,4,6,8,10,12,16$, 18 and 45 have been observed crystallographically. ${ }^{11-27}$ The simplest water cluster $\left(\mathrm{H}_{2} \mathrm{O}\right)_{2}$ has been crystallographically characterized in the cavity of a cryptand, ${ }^{25}$ and also in metal-organic framework materials. ${ }^{26,27}$ During the course of our investigations of compounds derived from organic ammonium 
cations containing inorganic anions like tetrathiomolybdate $^{31-33}$ and tetrathiotungstate ${ }^{34-36}$ we have identified a supramolecular water dimer in the crystal structure of a quaternary diammonium dichloride trihydrate (dbtmen) $\mathrm{Cl}_{2} \cdot 3 \mathrm{H}_{2} \mathrm{O} \quad \mathbf{1}$ (dbtmen is $\mathrm{N}, \mathrm{N}^{\prime}$ dibenzyl-N,N,N',N'-tetramethylethylenediammonium) and these results are described in this paper.

\section{Experimental}

All the chemicals used in this study were of reagent grade and were used as received. Infrared spectra were recorded on a Shimadzu FT-IR spectrometer (IR Prestige-21) in the range $4000-400 \mathrm{~cm}^{-1}$. The samples were prepared as $\mathrm{KBr}$-diluted pellets in the solid state and the infrared signals referenced to polystyrene bands. Electronic spectra were recorded in water using matched quartz cells on a Shimadzu (UV-2450) spectrophotometer. Isothermal weight loss studies were carried out in a temperature controlled oven. TG-DTA studies were performed in $\mathrm{Ar}$ atmosphere in the temperature range $30^{\circ}$ to $400^{\circ} \mathrm{C}$ on a Netzsch Simultaneous Thermal analyses apparatus. A heating rate of $10^{\circ} \mathrm{C} / \mathrm{min}$ was chosen for the measurement.

\subsection{Preparation of (dbtmen) $\mathrm{Cl}_{2} \cdot 3 \mathrm{H}_{2} \mathrm{O} 1$}

Benzyl chloride $(2.5 \mathrm{ml})$ was slowly added in drops to a cooled solution of tetramethylethylenediamine (tmen) $(1.5 \mathrm{ml})$ dissolved in $\mathrm{CH}_{3} \mathrm{CN}(5 \mathrm{ml})$ with constant stirring. (Caution! Benzyl chloride is lachrymatory and hence the synthesis is to be performed in a well-ventilated fume cupboard.) The reaction is exothermic in nature and initially the reaction mixture appears turbid. When the addition of benzyl chloride was complete copious amounts of white solid separated out. The product was filtered and washed with ether and dried in air. Yield: $3.35 \mathrm{~g}$ $(83 \%)$. Recrystallization of this product from water afforded crystalline blocks of $\mathbf{1}$ suitable for X-ray studies.

Analysis - Found (calc.) for $\mathrm{C}_{20} \mathrm{H}_{30} \mathrm{~N}_{2} \mathrm{Cl}_{2} \cdot 3 \mathrm{H}_{2} \mathrm{O}$, 1: C 56.31 (56.72); H 8.31 (8.58); N 5.68 (6.61); Cl $15.91(16 \cdot 74) \%$.

IR data in $\mathrm{cm}^{-1}: 3429(\mathrm{~s}), 3360$ (s), $3234(\mathrm{~m})$, 3028 (s), $3011(\mathrm{~s}), 2998(\mathrm{~s}), 2962(\mathrm{w}), 1620(\mathrm{~m})$, 1477 (s), $1461(\mathrm{~s}), 1414(\mathrm{~m}), 1395(\mathrm{w}), 1216(\mathrm{~m})$, $1164(w), 1082(w), 1033(w), 1002(m), 975(m)$, $927(\mathrm{~m}), 885(\mathrm{~s}), 781(\mathrm{~s}), 725(\mathrm{~s}), 705(\mathrm{~s}), 628(\mathrm{~s})$, $538(\mathrm{~m}), 499(\mathrm{w})$.

\subsection{Single crystal $X$-ray diffractometry}

Intensity data for $\mathbf{1}$, were collected on a Stoe Image Plate Diffraction System using graphite monochromated $\mathrm{Mo}-\mathrm{K}_{\alpha}$ radiation at $170 \mathrm{~K}$. The intensities were corrected for Lorentz polarization effects. The structure was solved with direct methods using SHELXS- $97^{37}$ and refinement was done against $F^{2}$ using SHELXL-97. ${ }^{37}$ All non-hydrogen atoms were refined using anisotropic displacement parameters. The $\mathrm{C}-\mathrm{H}$ hydrogen atoms were positioned with idealized geometry and refined isotropically using a riding model. The positions of the $\mathrm{O}-\mathrm{H}$ hydrogen atoms were located in the difference map, their bond lengths set to ideal values and were refined isotropic using a riding model with $\mathrm{O}-\mathrm{H}=0.86 \AA$. The $\mathrm{O} 3$ atom of one of the water molecules is disordered and was refined using a split model. The technical details of data acquisition and some selected crystal refinement results are summarized in table 1 .

Table 1. Crystal data and structure refinement for $\mathrm{N}, \mathrm{N}^{\prime}-$ dibenzyl-N,N, $\mathrm{N}^{\prime}, \mathrm{N}^{\prime}$-tetramethylethylenediammonium dichloride trihydrate $\mathbf{1}$.

\begin{tabular}{|c|c|}
\hline Molecular formula & $\mathrm{C}_{20} \mathrm{H}_{36} \mathrm{Cl}_{2} \mathrm{~N}_{2} \mathrm{O}_{3}$ \\
\hline Formula weight & $423 \cdot 41$ \\
\hline Temperature & $170(2) \mathrm{K}$ \\
\hline Wavelength & $0.71073 \AA$ \\
\hline Crystal system & Monoclinic \\
\hline Space group & $P 2_{1} / C$ \\
\hline Unit cell dimensions & $\begin{array}{l}a=22 \cdot 0744(15) \AA \\
b=9 \cdot 0525(7) \AA \\
c=11 \cdot 5433(7) \AA \\
\beta=97 \cdot 82(1)^{\circ}\end{array}$ \\
\hline Volume & $2285 \cdot 2(3) \AA^{3}$ \\
\hline Z & 4 \\
\hline Density (calculated) & $1 \cdot 231 \mathrm{Mg} / \mathrm{m}^{3}$ \\
\hline Absorption coefficient & $0 \cdot 305 \mathrm{~mm}^{-1}$ \\
\hline$F(000)$ & 912 \\
\hline Crystal size & $0.5 \times 0.4 \times 0.4 \mathrm{~mm}^{3}$ \\
\hline Theta range for data collection & $2 \cdot 44$ to $26 \cdot 92^{\circ}$ \\
\hline Index ranges & $\begin{array}{l}-20 \leq h \leq 28 \\
-11 \leq k \leq 11 \\
-14 \leq 1 \leq 14\end{array}$ \\
\hline Reflections collected & 10799 \\
\hline Independent reflections & $4782[R($ int $)=0 \cdot 0458]$ \\
\hline Completeness to theta $=26.92^{\circ}$ & $96 \cdot 4 \%$ \\
\hline Refinement method & $\begin{array}{l}\text { Full-matrix } \\
\text { least-squares on } F^{2}\end{array}$ \\
\hline Data/restraints/parameters & $4782 / 0 / 249$ \\
\hline Goodness-of-fit on $F^{2}$ & $1 \cdot 032$ \\
\hline Final $R$ indices $[I>2 \operatorname{sigma}(I)]$ & $\begin{array}{l}R 1=0.0484 \\
w R 2=0.1388\end{array}$ \\
\hline$R$ indices (all data) & $\begin{array}{l}R 1=0.0620 \\
w R 2=0.1464\end{array}$ \\
\hline Largest diff. peak and hole & 0.284 and $-0.339 e \AA^{-3}$ \\
\hline
\end{tabular}




\section{Results and discussion}

The synthesis of the hydrated organic diammonium dichloride $\mathbf{1}$ was accomplished by reacting the organic diamine tmen with benzyl chloride in a 1:2 molar ratio in $\mathrm{CH}_{3} \mathrm{CN}$ followed by recrystallization from water. This method is essentially similar to the one employed by us for the synthesis of the corresponding dibromide dihydrate.$^{38}$ It is interesting to note that, unlike the related unbenzylated dichloride $\left.(\operatorname{tmenH})_{2}\right) \mathrm{Cl}_{2}$ (tmenH $H_{2}$ is $\mathrm{N}, \mathrm{N}, \mathrm{N}^{\prime}, \mathrm{N}^{\prime}$-tetramethylethylenediammonium) which is anhydrous, ${ }^{39} \mathbf{1}$ crystallizes as a trihydrate. The compound analyzed satisfactorily for the proposed formula. The electronic spectrum of $\mathbf{1}$ exhibits a signal at $\sim 263 \mathrm{~nm}$ which can be assigned to the charge transfer of the aromatic moiety. The proton magnetic resonance spectrum of $\mathbf{1}$ in $\left(\mathrm{D}_{2} \mathrm{O}\right)$ exhibits four sharp singlets at $\delta 7.41 \mathrm{ppm}(\mathrm{s}, 10 \mathrm{H}), \delta$ $4.49 \mathrm{ppm}(\mathrm{s}, 4 \mathrm{H}), \delta 3.86 \mathrm{ppm}(\mathrm{s}, 4 \mathrm{H}), 3.02(\mathrm{~s}, 12 \mathrm{H})$, which can be assigned to the resonance absorptions of the aromatic, benzylic, methylene and methyl protons respectively. The observed chemical shifts are in the range observed for the corresponding dibromide dihydrate. ${ }^{38}$ The IR spectrum of the hydrated dichloride exhibits intense signals for the $\mathrm{O}-\mathrm{H}$ stretching vibrations bands at $3429,3360 \mathrm{~cm}^{-1}$ and these values are about $35 \mathrm{~cm}^{-1}$ lower in energy as compared to the corresponding H-bonded dibromide dihydrate which absorbs at 3464 and $3394 \mathrm{~cm}^{-1}$. The signal at $1616 \mathrm{~cm}^{-1}$ can be assigned for the $\mathrm{O}-\mathrm{H}$ bending vibration in $\mathbf{1}$ and this value is very close to that $\left(1620 \mathrm{~cm}^{-1}\right)$ observed in the dibromide. Several bands in the mid IR can be attributed to the vibrations of the organic cation.

The quaternary diammonium dichloride trihydrate 1 crystallizes monoclinic in the centrosymmetric space group $P 2{ }_{1} / c$ with all atoms located in general positions. The structure of 1 consists of (dbtmen) ${ }^{2+}$ dication, two chloride anions and three crystal water molecules (figure 1). The bromide analogue of 1 namely (dbtmen) $\mathrm{Br}_{2} \cdot 2 \mathrm{H}_{2} \mathrm{O}$ is a dihydrate and crystallizes in the triclinic $P^{\overline{1}}$ space group. ${ }^{38}$ It is interesting to note that the pair of unbenzylated dihalides of tmen viz. $\left(\mathrm{tmenH}_{2}\right) \mathrm{X}_{2}(\mathrm{X}=\mathrm{Cl}, \mathrm{Br})$ are anhydrous and $\left(\mathrm{tmenH}_{2}\right)_{\mathrm{Cl}}$ crystallizes in the triclinic $P \overline{1}$ space group ${ }^{39}$ while $\left(\operatorname{tmen} \mathrm{H}_{2}\right) \mathrm{Br}_{2}$ crystallizes in the monoclinic $P 2_{1} / \mathrm{c}$ space group. ${ }^{40}$ The observed $\mathrm{C}-\mathrm{C}$ and $\mathrm{C}-\mathrm{N}$ bond lengths as well as the bond angles of the organic cation in $\mathbf{1}$ (table 2) are in the normal range and are in good agreement with those observed for the corresponding dibromide dihydrate (dbtmen) $\mathrm{Br}_{2} \cdot 2 \mathrm{H}_{2} \mathrm{O} .{ }^{38}$ The unbenzylated $\left(\operatorname{tmenH} \mathrm{H}_{2}\right) \mathrm{X}_{2}$ $(\mathrm{X}=\mathrm{Cl}, \mathrm{Br})$ compounds exhibit very strong $\mathrm{N}-$ $\mathrm{H} \cdots \mathrm{X}(\mathrm{X}=\mathrm{Cl}, \mathrm{Br})$ interactions between the organic cation and the anion. However, such interactions are not possible in $\mathbf{1}$ in view of the tetraalkylation of the $\mathrm{N}$ atoms.

An analysis of the crystal structure reveals that the organic cation, the chloride anions and the crystal waters are involved in four varieties of $\mathrm{H}$-bonding interactions namely $\mathrm{C}-\mathrm{H} \cdots \mathrm{Cl}, \mathrm{C}-\mathrm{H} \cdots \mathrm{O}, \mathrm{O}-\mathrm{H} \cdots \mathrm{O}$ and $\mathrm{O}-\mathrm{H} \cdots \mathrm{Cl}$ (table 3). The chloride anions function as $\mathrm{H}$-bond acceptors and the organic cation as $\mathrm{H}$-bond donors while the crystal waters function as $\mathrm{H}$-bond acceptors as well as donors. Both the $\mathrm{Cl}^{-}$ions are $\mathrm{H}$ bonded to the organic cation with the aid of several $\mathrm{C}-\mathrm{H} \cdots \mathrm{Cl}$ interactions and to two of the crystal water molecules via $\mathrm{O}-\mathrm{H} \cdots \mathrm{Cl}$ interactions (figure 2). The organic cation is further linked to the crystal water molecules via $\mathrm{C}-\mathrm{H} \cdots \mathrm{O}$ bonds (figure 2). The $\mathrm{O}-$ $\mathrm{H} \cdots \mathrm{O}$ interaction between two of the crystal water molecules and the $\mathrm{O}-\mathrm{H} \cdots \mathrm{Cl}$ bonds to the two chloride ions result in the formation of a five-membered cyclic dichloride $\left\{\mathrm{O}_{3} \mathrm{Cl}_{2}\right\}$ unit (only the $\mathrm{O}$ and $\mathrm{Cl}$ but not the $\mathrm{H}$ atoms are considered). The two crystal water molecules are linked to the two chloride ions via five short $\mathrm{O}-\mathrm{H} \cdots \mathrm{Cl}$ hydrogen bonds ranging from 2.32 to $2.37 \AA$. These interactions can account for the observed lower energies of the $\mathrm{O}-\mathrm{H}$ vibrations in the IR spectrum. The $\mathrm{Cl} \cdots \mathrm{H}$ distances are much shorter compared to $2.95 \AA$, the sum of their van der

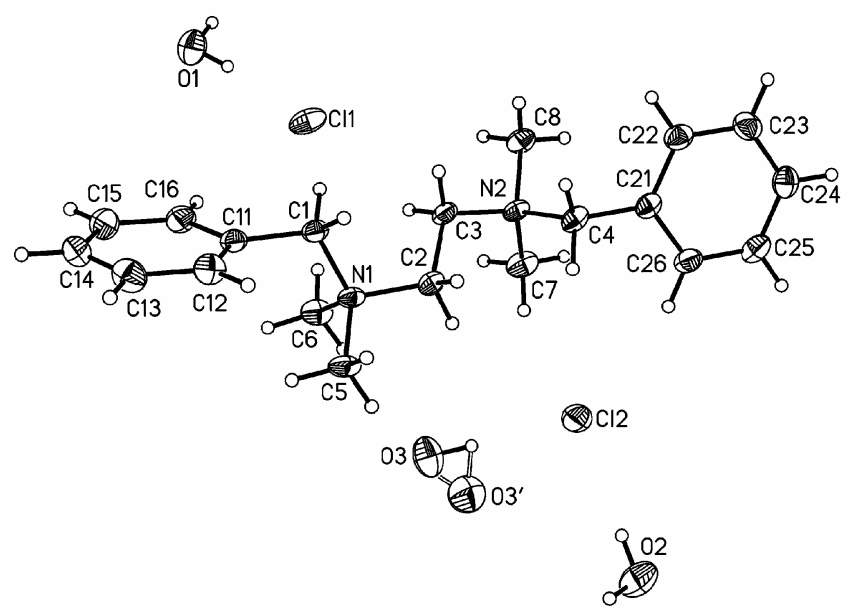

Figure 1. The asymmetric unit of (dbtmen) $\mathrm{Cl}_{2} \cdot 3 \mathrm{H}_{2} \mathrm{O} \mathbf{1}$ showing the atom-labelling scheme. The $\mathrm{O} 3$ atom is disordered. Displacement ellipsoids are drawn at the 50\% probability level except for the $\mathrm{H}$ atoms, which are shown as spheres of arbitrary radius. 
Table 2. Selected bond lengths $[\AA]$ and bond angles $\left[{ }^{\circ}\right]$ for $\mathbf{1}$.

\begin{tabular}{llll}
\hline Bond lengths & & & \\
$\mathrm{N}(1)-\mathrm{C}(6)$ & $1 \cdot 503(2)$ & $\mathrm{N}(2)-\mathrm{C}(3)$ & $1 \cdot 508(2)$ \\
$\mathrm{N}(1)-\mathrm{C}(5)$ & $1 \cdot 508(2)$ & $\mathrm{N}(2)-\mathrm{C}(4)$ & $1 \cdot 528(2)$ \\
$\mathrm{N}(1)-\mathrm{C}(2)$ & $1 \cdot 509(2)$ & $\mathrm{C}(1)-\mathrm{C}(11)$ & $1 \cdot 504(2)$ \\
$\mathrm{N}(1)-\mathrm{C}(1)$ & $1 \cdot 527(2)$ & $\mathrm{C}(2)-\mathrm{C}(3)$ & $1 \cdot 530(3)$ \\
$\mathrm{N}(2)-\mathrm{C}(8)$ & $1 \cdot 505(2)$ & $\mathrm{C}(4)-\mathrm{C}(21)$ & $1 \cdot 498(3)$ \\
$\mathrm{N}(2)-\mathrm{C}(7)$ & $1 \cdot 506(2)$ & & \\
& & & \\
Bond angles & & & \\
$\mathrm{C}(6)-\mathrm{N}(1)-\mathrm{C}(5)$ & $108 \cdot 31(13)$ & $\mathrm{C}(7)-\mathrm{N}(2)-\mathrm{C}(3)$ & $111 \cdot 39(14)$ \\
$\mathrm{C}(6)-\mathrm{N}(1)-\mathrm{C}(2)$ & $111 \cdot 29(14)$ & $\mathrm{C}(8)-\mathrm{N}(2)-\mathrm{C}(4)$ & $110 \cdot 40(14)$ \\
$\mathrm{C}(5)-\mathrm{N}(1)-\mathrm{C}(2)$ & $106 \cdot 45(13)$ & $\mathrm{C}(7)-\mathrm{N}(2)-\mathrm{C}(4)$ & $111 \cdot 21(14)$ \\
$\mathrm{C}(6)-\mathrm{N}(1)-\mathrm{C}(1)$ & $111 \cdot 16(14)$ & $\mathrm{C}(3)-\mathrm{N}(2)-\mathrm{C}(4)$ & $108 \cdot 83(13)$ \\
$\mathrm{C}(5)-\mathrm{N}(1)-\mathrm{C}(1)$ & $110 \cdot 33(13)$ & $\mathrm{C}(11)-\mathrm{C}(1)-\mathrm{N}(1)$ & $115 \cdot 10(14)$ \\
$\mathrm{C}(2)-\mathrm{N}(1)-\mathrm{C}(1)$ & $109 \cdot 18(13)$ & $\mathrm{N}(1)-\mathrm{C}(2)-\mathrm{C}(3)$ & $112 \cdot 35(14)$ \\
$\mathrm{C}(8)-\mathrm{N}(2)-\mathrm{C}(7)$ & $108 \cdot 55(14)$ & $\mathrm{N}(2)-\mathrm{C}(3)-\mathrm{C}(2)$ & $113 \cdot 11(14)$ \\
$\mathrm{C}(8)-\mathrm{N}(2)-\mathrm{C}(3)$ & $106 \cdot 37(13)$ & $\mathrm{C}(21)-\mathrm{C}(4)-\mathrm{N}(2)$ & $115 \cdot 35(14)$ \\
\hline
\end{tabular}

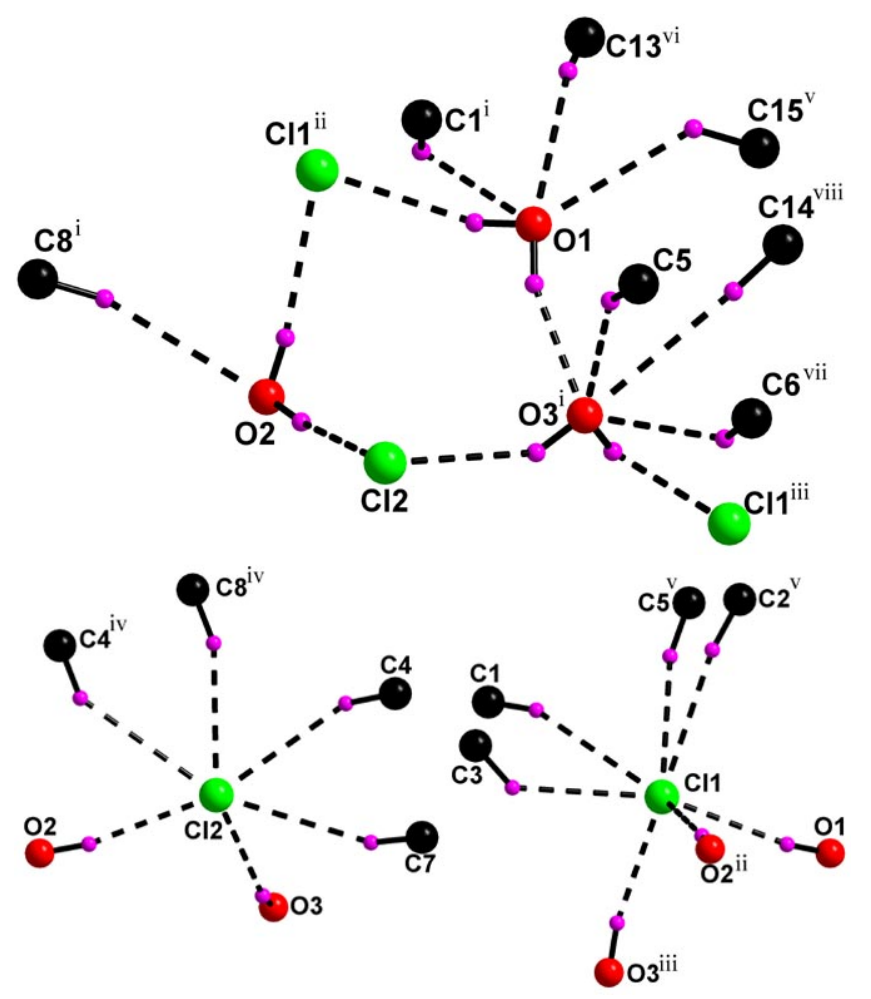

Figure 2. A view of the surroundings of the crystal water molecules showing the $\mathrm{O}-\mathrm{H} \cdots \mathrm{O}, \mathrm{O}-\mathrm{H} \cdots \mathrm{Cl}$ and $\mathrm{C}-\mathrm{H} \cdots \mathrm{O}$ interactions (top); The environment of the chloride anions showing the $\mathrm{O}-\mathrm{H} \cdots \mathrm{Cl}$ and $\mathrm{C}-\mathrm{H} \cdots \mathrm{Cl}$ interactions (bottom). Symmetry codes: (i) $x, y, z-1$ (ii) $x, y, z+1$ (iii) $x$, $-y+1 / 2, z+1 / 2$ (iv) $x,-y+3 / 2, z-1 / 2$ (v) $x,-y+3 / 2$, $z+3 / 2$ (vi) $-x+1,-y+1,-z$ (vii) $-x+1, y+1 / 2$, $-z+1 / 2$ (viii) $-x+1,-y+1,-z+1$.

Waals radii ${ }^{41}$ and are accompanied by $\mathrm{O}-\mathrm{H} \cdots \mathrm{Cl}$ angles ranging from 143 to $172^{\circ} . \mathrm{Cl} 2$ is involved in two short $\mathrm{O}-\mathrm{H} \cdots \mathrm{Cl}$ interactions one each with $\mathrm{O} 2$

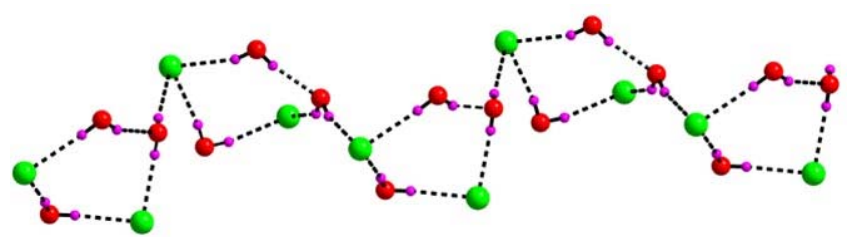

Figure 3. Formation of a chain of H-bonded fivemembered rings. The rings are linked with the aid of O3$\mathrm{H} 2 \mathrm{O} 3 \cdots \mathrm{Cl} 1$ interaction.

and $\mathrm{O} 3$ while $\mathrm{Cl} 1$ makes three short $\mathrm{Cl} \cdots \mathrm{H}$ contacts, one each with all the oxygen atoms. In the fivemembered ring, $\mathrm{Cl1}$ is hydrogen bonded to $\mathrm{O} 1$ and $\mathrm{O} 2$. The $\mathrm{O} 3-\mathrm{H} 2 \mathrm{O} 3 \cdots \mathrm{Cl} 1$ interaction links one fivemembered ring with the next leading to the formation of a H-bonded chain of five-membered rings (figure $3)$. The five-membered ring contains a supramolecular water dimer due to the linking of 01 with $\mathrm{O} 3$. The observed $\mathrm{O} 1 \cdots \mathrm{O} 3$ distance of $2.806 \AA$ in $\mathbf{1}$ is comparable with the reported $\mathrm{O} \cdots \mathrm{O}$ distances for water dimers in other environments. ${ }^{25-27}$ The formation of the $\mathrm{H}$-bonded chain of five-membered rings can be explained by comparing the structure of 1 with that of the corresponding dibromide dihydrate (dbtmen) $\mathrm{Br}_{2} \cdot 2 \mathrm{H}_{2} \mathrm{O}$. In the dibromide compound a $\mathrm{H}$-bonded four membered cyclic dibromide unit $\left\{\mathrm{O}_{2} \mathrm{Br}_{2}\right\}$ was observed and the four-membered rings were isolated but not linked into a chain as in $\mathbf{1}$. The four $\mathrm{O}_{-}$ $\mathrm{H} \cdots \mathrm{Br}$ interactions between the bromide and the two crystal water molecules ranging from 2.472 to $2.528 \AA$ in the dibromide compound resulted in the formation of alternating layers of (dbtmen $)^{+2}$ cation and cyclic hydrogen-bonded dibromides. This structural difference can be attributed to the different de- 
Table 3. Hydrogen-bonding geometry $\left(\AA,^{\circ}\right)$ for (dbtmen) $\mathrm{Cl}_{2} \cdot 3 \mathrm{H}_{2} \mathrm{O} 1$.

\begin{tabular}{|c|c|c|c|c|}
\hline $\mathrm{D}-\mathrm{H} \cdots \mathrm{A}$ & $d(\mathrm{D}-\mathrm{H})$ & $d(\mathrm{H} \cdots \mathrm{A})$ & $d(\mathrm{D} \cdots \mathrm{A})$ & $<$ DHA \\
\hline $\mathrm{O} 1-\mathrm{H} 1 \mathrm{O} 1 \cdots \mathrm{O} 3^{\mathrm{i}}$ & $0 \cdot 86$ & 1.99 & $2 \cdot 806(7)$ & 159 \\
\hline $\mathrm{O} 1-\mathrm{H} 2 \mathrm{O} 1 \cdots \mathrm{Cl} 1$ & 0.86 & $2 \cdot 37$ & $3 \cdot 199(10)$ & 163 \\
\hline $\mathrm{O} 2-\mathrm{H} 1 \mathrm{O} 2 \cdots \mathrm{Cl} 1^{\mathrm{ii}}$ & 0.86 & $2 \cdot 36$ & $3 \cdot 218(6)$ & 172 \\
\hline $\mathrm{O} 2-\mathrm{H} 2 \mathrm{O} 2 \cdots \mathrm{Cl} 2$ & $0 \cdot 86$ & $2 \cdot 34$ & $3 \cdot 185(2)$ & 168 \\
\hline $\mathrm{O} 3-\mathrm{H} 1 \mathrm{O} 3 \cdots \mathrm{Cl} 2$ & 0.86 & 2.35 & $3.081(7)$ & 143 \\
\hline $\mathrm{O} 3-\mathrm{H} 2 \mathrm{O} 3 \cdots \mathrm{C} 11^{\mathrm{iii}}$ & 0.86 & $2 \cdot 32$ & $3 \cdot 147(2)$ & 162 \\
\hline $\mathrm{C} 4-\mathrm{H} 4 \mathrm{~A} \cdots \mathrm{Cl} 2^{\mathrm{iv}}$ & 0.99 & $2 \cdot 88$ & $3 \cdot 706(6)$ & 146 \\
\hline $\mathrm{C} 8-\mathrm{H} 8 \mathrm{~B} \cdots \mathrm{Cl} 2^{\mathrm{iv}}$ & 0.98 & $2 \cdot 72$ & $3.634(2)$ & 156 \\
\hline C4-H4B ‥Cl2 & 0.99 & $2 \cdot 80$ & $3 \cdot 741(5)$ & 153 \\
\hline $\mathrm{C} 7-\mathrm{H} 7 \mathrm{~B} \cdots \mathrm{Cl} 2$ & 0.98 & $2 \cdot 83$ & $3.735(5)$ & 154 \\
\hline 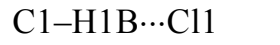 & 0.99 & $2 \cdot 84$ & $3 \cdot 766(8)$ & 156 \\
\hline C3-H3A ‥Cl1 & 0.99 & $2 \cdot 72$ & $3 \cdot 504(11)$ & 137 \\
\hline $\mathrm{C} 5-\mathrm{H} 5 \mathrm{~B} \cdots \mathrm{Cl1}{ }^{\mathrm{v}}$ & 0.98 & 2.78 & $3 \cdot 681(3)$ & 153 \\
\hline $\mathrm{C} 2-\mathrm{H} 2 \mathrm{~B} \cdots \mathrm{C} 11^{\mathrm{v}}$ & 0.99 & 2.79 & $3 \cdot 700(3)$ & 154 \\
\hline $\mathrm{C} 1-\mathrm{H} 1 \mathrm{~A} \cdots \mathrm{O} 1^{\mathrm{i}}$ & 0.99 & $2 \cdot 60$ & $3 \cdot 439(2)$ & 143 \\
\hline $\mathrm{C} 15-\mathrm{H} 15 \cdots \mathrm{O} 1^{v}$ & 0.95 & $2 \cdot 64$ & $3 \cdot 348(15)$ & 132 \\
\hline $\mathrm{C} 13-\mathrm{H} 13 \cdots \mathrm{O} 1^{\mathrm{vi}}$ & 0.95 & $2 \cdot 62$ & $3 \cdot 500(11)$ & 155 \\
\hline $\mathrm{C} 8-\mathrm{H} 8 \mathrm{C} \cdots \mathrm{O} 2^{\mathrm{i}}$ & 0.98 & $2 \cdot 68$ & $3 \cdot 589(6)$ & 154 \\
\hline C6-H6A $\cdots 3^{\text {vii }}$ & 0.98 & $2 \cdot 64$ & $3 \cdot 493(10)$ & 146 \\
\hline $\mathrm{C} 5-\mathrm{H} 5 \mathrm{C} \cdots \mathrm{O} 3$ & 0.98 & $2 \cdot 51$ & $3 \cdot 402(6)$ & 152 \\
\hline $\mathrm{C} 14-\mathrm{H} 14 \cdots \mathrm{O}^{\text {viii }}$ & 0.95 & $2 \cdot 70$ & $3.635(8)$ & 167 \\
\hline
\end{tabular}

Symmetry codes: (i) $x, y, z-1$ (ii) $x, y, z+1$ (iii) $x,-y+1 / 2, z+1 / 2$ (iv) $x,-y+3 / 2$, $z-1 / 2$ (v) $x,-y+3 / 2, z+3 / 2$ (vi) $-x+1,-y+1,-z$ (vii) $-x+1, y+1 / 2,-z+1 / 2$ (viii) $-x+1,-y+1,-z+1$

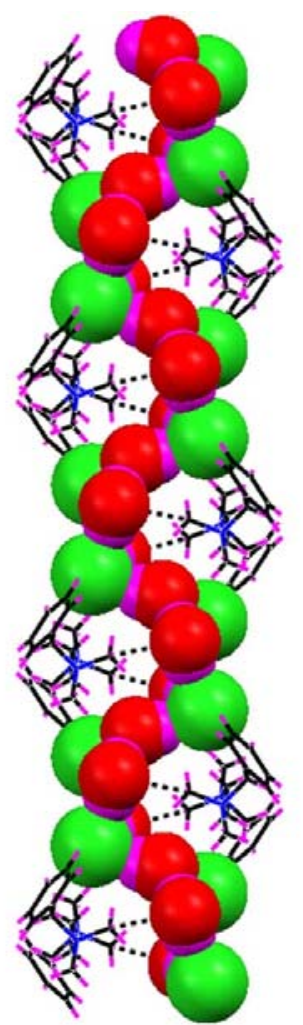

Figure 4. Supramolecular organization of the fivemembered $\left\{\mathrm{Cl}_{2} \mathrm{O}_{3}\right\}$ rings into a spiral-like chain. The organic cations are organised in zigzag fashion on either side of the chain. grees of hydration of $\mathbf{1}$ and the dibromide. Unlike in the dibromide, the H-bonded five-membered cyclic $\left\{\mathrm{O}_{3} \mathrm{Cl}_{2}\right\}$ units in $\mathbf{1}$ are linked into a spiral-like chain (figure 4). The seven $\mathrm{C}-\mathrm{H} \cdots \mathrm{O}$ distances ranging from 2.51 to $2.70 \AA$ and the eight $\mathrm{C}-\mathrm{H} \cdots \mathrm{Cl}$ distances ranging from 2.72 to $2.88 \AA$ indicate several weak contacts ${ }^{42}$ between the organic cation and the anionic water chain. The supramolecular organization of the organic cations in a zigzag fashion on either side of the anionic water chain to promote weak non-bonding interactions can probably explain the spiral-like shape of the chain.

The thermal stability of (dbtmen) $\mathrm{Cl}_{2} \cdot 3 \mathrm{H}_{2} \mathrm{O} \mathbf{1}$ was investigated by isothermal weight loss studies as well as TG-DTA measurements. A mass loss of around 11\% was observed when 1 is heated at $100^{\circ} \mathrm{C}$ on a water bath for about $10 \mathrm{~min}$. The observed mass change is slightly less than that to that expected $(12.75 \%)$ for the loss of three moles of water. The observed mass loss of $\mathbf{1}$ after heating at $150^{\circ} \mathrm{C}$ is about $12.62 \%$ and this value is in very good agreement with that expected for the emission of three moles of water. However, the IR spectrum of the heat-treated product was very similar to that of the starting material indicating that the anhydrous sample is quite moisturesensitive and reabsorbs water. Our several attempts to record the IR spectrum of the dehydrated sample 


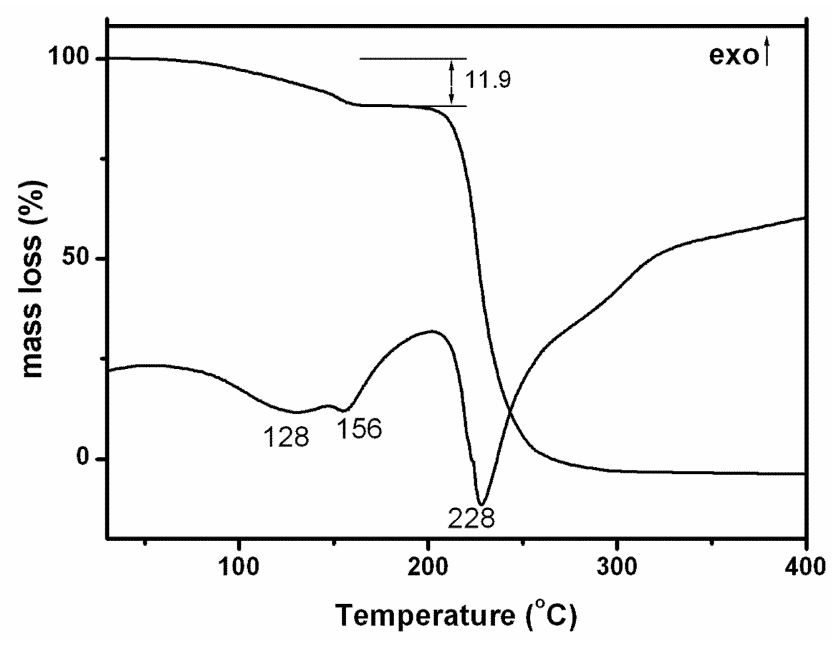

Figure 5. TG-DTA curves for (dbtmen) $\mathrm{Cl}_{2} \cdot 3 \mathrm{H}_{2} \mathrm{O} \quad \mathbf{1}$ (decomposition in flowing Ar).

were not successful. The affinity of the dehydrated sample for moisture can also be evidenced by the fact that the bulk of the dehydrated sample regains its original weight by just exposure to air within $10 \mathrm{~min}$. The IR spectrum of this final product is identical to that of $\mathbf{1}$. It is to be noted that in the case of the corresponding bromide analogue the rehydration experiment was performed by equilibrating the anhydrous dibromide over water in a dessicator. ${ }^{36}$ It is also noted that extended exposure times or equilibration over water of the anhydrous product does not result in the formation of any other product containing more than three moles of water. The TG-DTA experiment gave a very similar result and the thermogram (figure 5) exhibits endothermic events with a broad signal at around $128^{\circ} \mathrm{C}$ and another signal at $156^{\circ} \mathrm{C}$, which can be attributed to the dehydration of 1. On further heating, the anhydrous compound formed, undergoes endothermic decomposition at around $228^{\circ} \mathrm{C}$. The compound is fully pyrolysed without leaving any residue.

\section{Conclusions}

In summary, we have described the synthesis, spectral, thermal and structural characterization of the organic diammonium dichloride trihydrate (dbtmen) $\mathrm{Cl}_{2}$. $3 \mathrm{H}_{2} \mathrm{O}$ 1, which exhibits four varieties of $\mathrm{H}$-bonds. The $\mathrm{O}-\mathrm{H} \cdots \mathrm{Cl}$ and $\mathrm{O}-\mathrm{H} \cdots \mathrm{O}$ interactions between the chloride anions and the crystal water molecules lead to the formation of cyclic dichloride rings containing water dimers. The rings thus formed are linked into spiral-like chains with the help of $\mathrm{O}-\mathrm{H} \cdots \mathrm{Cl}$ interactions. The organic cations are organised on either side of the anionic water chain and linked by weak $\mathrm{C}-\mathrm{H} \cdots \mathrm{O}$ and $\mathrm{C}-\mathrm{H} \cdots \mathrm{Cl}$ interactions. Compound 1 emits water on heating and reabsorbs water when the dehydrated sample is exposed to air or moisture. The present work constitutes an example of the identification of a water dimer in a quaternary diammonium dichloride.

\section{Acknowledgements}

BRS thanks A R Naik and P Raghavaiah for helpful discussions, and the Department of Science and Technology, New Delhi for financial support.

\section{Supplementary material}

Crystallographic data (excluding structure factors) for the structure reported in this paper have been deposited with the Cambridge Crystallographic Data Centre as supplementary publication no. CCDC 614322 (1). Copies of the data can be obtained, free of charge, on application to CCDC, 12 Union Road, Cambridge CB2 1 EZ, UK (fax: +44-(0)1223-336033 or email: deposit@ccdc.cam.ac.uk).

\section{References}

1. Jayaraman K, Chaudhary A and Rao C N R 2002 Solid State Sci. 4413

2. Raghavaiah P, Supriya S and Das S K 2005 Cryst. Eng. Commun. 7167

3. Raghavaiah P, Supriya S and Das S K 2006 Chem. Commun. 2762

4. Ludwig R 2001 Angew. Chem. Int. Ed. 401808

5. Infantes L and Motherwell S 2002 Cryst. Eng. Commun. 4454

6. Infantes L, Chisolm J and Motherwell S 2003 Cryst. Eng. Commun. 5480

7. Mascal M, Infantes L and Chisolm J 2006 Angew. Chem. Int. Ed. 4532

8. Liu K, Cruzan J D and Saykally R J 1996 Science 271929

9. Maheswari S, Patel N, Sathyamurthy N, Kulkarni A D and Gadre S R 2001 J. Phys. Chem. 10510525

10. Keutsch F N, Cruzan J D and Saykally R J 2003 Chem. Rev. 1032533

11. Chacko K K and Saenger W 1981 J. Am. Chem. Soc. 10371708

12. Supriya S, Manikumari S, Raghavaiah P and Das S K 2003 New J. Chem. 27218

13. Srinivasan B R, Sawant J V, Näther C and Bensch W (unpublished results) 
14. Long L S, Wu Y R, Huang R B and Zheng L S 2004 Inorg. Chem. 433798

15. Ghosh S K and Bharadwaj P K 2004 Inorg. Chem. 43 5180

16. Doedens R J, Yohannes E and Khan M I 2002 Chem. Commun. 62

17. Prasad T K and Rajasekharan M V 2006 Cryst. Growth Design 6488

18. Atwood J L, Barbour L J, Ness T J, Raston C L and Raston P L 2001 J. Am. Chem. Soc. 1237192

19. Neogi S, Savitha G and Bharadwaj P K 2004 Inorg. Chem. 433771

20. Ma B Q, Sun H L and Gao S 2004 Angew. Chem. Int. Ed. 43

21. Ghosh S K and Bharadwaj P K 2004 Angew. Chem. Int. Ed. 43

22. Ghosh S K and Bharadwaj P K 2004 Inorg. Chem. 43 6887

23. Raghuraman K, Katti K K, Barbour L J, Pillarsetty N, Barnes C L and Katti K V 2003 J. Am. Chem. Soc. 1256955

24. Lakshminarayanan P S, Suresh E and Ghosh P 2005 J. Am. Chem. Soc. 12713132

25. Chand D K and Bharadwaj P K 1998 Inorg. Chem. 37 5050

26. Sujit K G and Bharadwaj P K 2003 Inorg. Chem. 42 8250

27. Manikumari S, Shivaiah V and Das S K 2002 Inorg. Chem. 416953

28. Dyke T R, Mack K M and Muenter J S 1977 J. Chem. Phys. 66498
29. Odutola J A and Dyke T R 1980 J. Chem. Phys. 72 5062

30. Vernon M F, Krajnovich D J, Kwok H S, Lisy J M, Shen Y R and Lee Y T 1982 J. Chem. Phys. 7747

31. Srinivasan B R, Dhuri S N, Näther C and Bensch W 2005 Inorg. Chim. Acta 358279

32. Srinivasan B R, Näther C and Bensch W 2006 Acta Crystallogr. C62 m98

33. Srinivasan B R, Näther C and Bensch W 2005 Acta Crystallogr. E61 m2454; Srinivasan B R, Nather C Naik A R and Bensch W 2006 Acta Crystallogr. E62 m1635

34. Srinivasan B R, Dhuri S N, Poisot M, Näther C and Bensch W 2005 Z. Anorg. Allg. Chem. 6311087

35. Srinivasan B R, Näther C, Dhuri S N and Bensch W 2006 Monats. Chem. 137397

36. Srinivasan B R, Näther C, Dhuri S N and Bensch W 2006 Polyhedron 253269

37. Sheldrick G M 1997 SHELXS-97 and SHELXL-97: Programs for crystal structure solution and refinement, University of Gottingen, Germany

38. Srinivasan B R, Dhuri S N, Sawant J V, Näther C and Bensch W 2006 J. Chem. Sci. 118211

39. Kabak M, Elerman Y, Ünaleroglu C, Mert Y and Durlu T N 2000 Acta Crystallogr. C56 e66

40. Annan T A, Chadha R K and Tuck D G 1991 Acta Crystallogr. C47 151

41. Bondi A 1964 J. Phys. Chem. 68441

42. Desiraju G R and Steiner T 1999 The weak hydrogen bond in structural chemistry and biology (Oxford: University Press) 